САМООСВІТНЯ КОМПЕТЕНТНІСТЬ ЯК РЕЗУЛЬТАТ СВІДОМОГО ПІДВИЩЕННЯ КВАЛІФІКАЦІЇ ВИКЛАДАЧА ВИЩОЇ ШКОЛИ

\title{
SELF-EDUCATIONAL COMPETENCE AS A RESULT OF A CONSCIOUS UPGRADING SKILLS FOR A TEACHER OF A HIGHER EDUCATIONAL INSTITUTION
}

Стаття присвячена проблемі самоосвітньої компетентності викладача закладу вищої освіти як важливому чиннику його позитивної самозміни відповідно до нових вимог часу і суспільства. На основі аналізу наукових праць визначено, що означена проблема передусім представлена в аспекті формування майбутніх фрахівців різних галузей та організації процесу підвищення кваліфрікації викладачів. Спираючись на вимоги до науково-педагогічних працівників, представлені в оновлених нормативних документах, визначили необхідним виокремити із загального наукового дискурсу конкретну проблему - підвищення кваліфрікації викладачів ЗВО шляхом диверсифікованих фрорм за накопичувальною системою. Визначено основні компетениії викладача закладу вищоі освіти (предметну, методичну, психологопедагогічну, комунікативну, інфрормаційнотехнологічну, управлінсько-організаційну, наукову) які загалом представляють його профресійну компетентність. Представлено досвід організації та проведення науково-практичної школи-семінару «Сучасні технології навчальної діяльності викладача закладу вищої освіти», реалізованого на постійній основі у формі тренінгу у Харківському національному університеті міського господарства імені О.М. Бекетова. Презентовано авторські курси з оновлення психолого-педагогічної («Коучингові технологіі у навчанні», «Технологія maind-mapping», «Технологія скрайбінгу») та наукової («Організація публікації у журналах провідних науково-метричних баз») компетентності викладача, які дозволяють спрямувати науково-педагогічних працівників вищої школи на застосування сучасних методів і технологій у взаємодії зі студентами. Доведено, що підвищення кваліфрікації викладачів ЗВО, яке здійснюється лонгітюдним способом (щороку по одному кредиту) за накопичувальною системою сприяє актуалізації ресрлексії науково-педагогічних працівників щодо власної недосконалості в аспекті сучасних вимог і їхньої активності у виборі формм $і$ способів професійного самовдосконалення. Зроблено висновок, що свідоме поступове накопичення актуального і сучасного педагогічного досвіду викладача університету свідчить про сформованість його самоосвітньої компетентності.

Ключові слова: самоосвітня компетентність, підвищення кваліфрікації, викладач закладу вищої освіти, професійна компетентність, технології навчання, накопичувальна система.

The article is devoted to the problem of selfeducational competence of a teacher of a higher education institution as an important factor of his/her positive self-change in accordance with the new requirements of time and society. On the basis of the analysis of scientific works, it is determined that this problem is primarily presented in terms of future professionals' training in various fields and the organization of the process of upgrading skills for teachers. On the ground of the requirements for researchers and teaching staff presented in the updated regulations, it is considered reasonable to isolate a specific problem in the general scientific discourse, namely, the problem of training teachers of higher educational institutions using diversified forms and the accumulative system. The main competencies of a teacher of a higher educational institution are determined: subject-matter, methodical, psychologicalpedagogical, communicative, informationtechnological, managerial-organizational, scientific competencies, which in general represent the professional competence of a teacher. The experience of organizing and conducting a scientific-practical schoolseminar "Modern technologies of educational activities of a teacher of a higher educational institution" implemented on a regular basis in the form of trainings at O.M. Beketov National University of Urban Economy in Kharkiv is presented. Proprietary courses for updating psychological-pedagogical competence ("Coaching technologies in teaching", "Mindmapping technology", "Scribing technology") and scientific competence ("Organization of a publication in the leading scientometric journals") of a teacher are introduced, which allow to encourage researchers and pedagogical staff of higher educational establishments to use modern methods and technologies in the interaction with students. It is proved that upgrading skills training for teachers of higher educational establishments, which is carried out using a longitudinal method (one credit each year) and the accumulative system, helps to actualize the reflection of the researchers and the teaching staff on their own imperfection in terms of modern requirements as well as their activity in choosing forms and methods of professional self-improvement. It is concluded that a conscious gradual accumulation of relevant and modern pedagogical experience of the university teacher indicates the formation of his/her self-educational competence.

Key words: self-educational competence, upgrading skills training, teacher of a higher educational establishment, professional competence, educational technologies, accumulative system.
Постановка проблеми у загальному вигляді. Швидкоплинність інфрормаційних процесів у сучасному світі створює необхідність для будь-яких фахівців, зокрема педагогів, відповідати професійним вимогам, що постійно оновлюються згідно із запитами суспільства. Орієнтація української 
вищої освіти на загальноєвропейські освітні стандарти стала викликом щодо оновлення профресійних компетенцій викладача (лектора і практика), які загалом становлять його профресійну компетентність.

Практика сучасної організації навчального процесу у вищій школі свідчить про важливість своєчасного усвідомлення викладачем власної недосконалості у певній професійній компетенції й рішення щодо підвищення її рівня шляхом самоосвіти - отже, йдеться про рефлексію самоосвітньої компетентності педагога.

Аналіз останніх досліджень і публікацій. Інтерес до проблеми самоосвіти суб'єктів педагогічного процесу у науковій думці представлено численними дослідженнями, в яких означене поняття екстраполюється через розуміння його зумовленості активністю особистості у пошуках способів самовдосконалення, рефлексивності щодо предмету профресійного оновлення, організованості й систематичності у набутті нових компетенцій. На думку Н. Самарук, самоосвітня компетентність розглядається як якість особистості та як її готовність і здатність до саморозвитку [5, с. 78]. Р. Перкатий трактує це поняття як цілісний інтегративний конструкт, що характеризує ставлення фрахівців до профресійної діяльності, передбачає готовність до безперервної самоосвіти упродовж життя, уміння організації та управління самоосвітою, а також застосування результатів самоосвітньої діяльності у профресії [3, с. 186]. У дослідженні Б. Вовк самоосвіта викладача зумовлюється його активністю, яка виникає під впливом зовнішніх стимулів та особистої мотивації [1, с. 185]. Прикладного значення самоосвіті викладачів надає Л. Кайдалова, розглядаючи її як процес підвищення кваліфікації, результатом чого стає, на думку науковця, профресійне й особистісне зростання педагогів [2, с. 42]. В аспекті означеної нами проблеми актуальною визначаємо думку Л. Кайдалової про зміст самоосвіти викладачів, що має бути зумовленим сучасними проблемами та подіями у світі, оскільки у системі освіти змінюються як потреби суспільства, так і вимоги до викладачів закладів вищої освіти [2, с. 43].

Виділення не вирішених раніше частин загальної проблеми. Реформування системи освіти спричинило умови для оновлення змісту державних нормативів щодо проблеми підвищення кваліфрікації науково-педагогічних працівників, зокрема у пункті обсягів, тривалості та фрорм реалізації означеного процесу. Так, у Постанові Кабінету Міністрів України № 800 від 21 серпня 2019 р. «Про порядок підвищення кваліфікації педагогічних і науково-педагогічних працівників» зазначено, що обсяг (тривалість) підвищення кваліфрікації установлюється за вимогами Європейської кредитної трансорерно-накопичувальної системи у межах одного кредиту (30 годин) за рік.
Видами підвищення кваліфрікації визначаються, крім навчання за основною програмою, участь у семінарах, практикумах, тренінгах, вебінарах, майстер-класах тощо [4]. 3 огляду на означене актуальною визначаємо проблему організації підвищення кваліфікації викладачів вищої школи шляхом накопичення кредитів у щорічних профресійно-педагогічних активностях.

Метою статті визначаємо представлення досвіду організації підвищення кваліфікації викладачів ЗВО шляхом науково-практичного семінару з метою формування їхньої самоосвітньої компетентності.

Виклад основного матеріалу. Зміна нормативних підходів до процесу підвищення кваліфікації викладачів вищої школи спонукала знаходити нові шляхи організації означеного процесу. Передусім було визначено компетенції викладача закладу вищої освіти, кожна 3 яких може бути оновленою внаслідок особистісної рефлексії самого викладача та потреб його фрахової діяльності. Зауважуємо, що будь-яка за змістом компетенція визначена індикатором якості освіти згідно із представленням структурної рефрорми вищої освіти у межах Болонського процесу. Це складне системне утворення, яке містить професійні знання, уміння, способи та техніки фрахової діяльності, сукупність установок та орієнтацій, набутий досвід, що дає змогу викладачеві досягати високих освітніх результатів. Отже, підвищення якості вищої освіти безпосередньо пов'язане з розвитком компетенцій профресорсько-викладацького складу університетів.

Основними компетенціями викладача $3 \mathrm{BO}$ визначено предметну (дисциплінарну), методичну (дидактичну), психолого-педагогічну, комунікативну, інформаційно-технологічну, управлінськоорганізаційну та наукову. Зміст кожної з компетенцій наведено у таблиці.

3 огляду на те, що кожна із професійних компетенцій має систематично оновлюватися і змістово та технологічно збагачуватися шляхом підвищення викладачем професійної кваліфікації, фрахівці кафедри мовної підготовки, педагогіки та психології Харківського національного університету міського господарства імені О.М. Бекетова ініціювали розробку та реалізацію курсу постійно діючої науково-практичної школи-семінару «Сучасні технології навчальної діяльності викладача закладу вищої освіти», реалізованої на постійній основі у фрормі тренінгу. Зауважуючи на вимоги до підвищення кваліфрікації науково-педагогічними працівниками, викладені в оновленому Положенні, орієнтувалися на можливості регулярного професійного «тюнінгу» викладача. Означені виклики були реалізовані через розробку авторських програм підвищення кваліфрікації, зокрема для удосконалення психолого-педагогічної («Технологія 
Основні компетенції викладача 3Во, що виявляють рівень його професійної компетентност

Таблиця
ентності

\begin{tabular}{|c|c|c|}
\hline компетенція & зміст виявлення & шляхи розвитку \\
\hline $\begin{array}{l}\text { Предметна } \\
\text { (дисциплінарна) }\end{array}$ & $\begin{array}{l}\text { оновлення профресійних знань; } \\
\text { Інноваційність; } \\
\text { практикоорієнтованість (уміння застосувати зна- } \\
\text { ння) }\end{array}$ & $\begin{array}{l}\text { активність користування інфрорма- } \\
\text { ційними джерелами; } \\
\text { підвищення кваліфікації з дисци- } \\
\text { пліни викладання; } \\
\text { участь у практичних тренінгах, } \\
\text { семінарах }\end{array}$ \\
\hline Методична (дидактична) & $\begin{array}{l}\text { здатність застосовувати різні способи організації } \\
\text { навчальної діяльності студентів; } \\
\text { здатність до цільового планування навчальних } \\
\text { занять, реалізації основних частин заняття; } \\
\text { здатність орієнтуватись на компетенції, що мають } \\
\text { бути сформовані у майбутніх фахівців (контек- } \\
\text { стне навчання); } \\
\text { здатність до створення дидактичних матеріалів } \\
\text { для занять; } \\
\text { здатність до корекції методичних підходів у } \\
\text { організації навчального процесу відповідно до } \\
\text { стандартів освіти та рівня досягнень студентів } \\
\text { (рефрлексія) }\end{array}$ & $\begin{array}{l}\text { підвищення педагогічної кваліфі- } \\
\text { кації; } \\
\text { участь у методичних семінарах, } \\
\text { конореренціях; } \\
\text { робота у складі циклових предмет- } \\
\text { них комісій }\end{array}$ \\
\hline Психолого-педагогічна & $\begin{array}{l}\text { здатність до мотивації та стимулювання навчаль- } \\
\text { ної діяльності студентів; } \\
\text { виявлення професійної позиції у процесі фрорму- } \\
\text { вання ціннісної системи студентів; } \\
\text { авторитетність; } \\
\text { уміння створювати комфрортні умови для } \\
\text { навчання }\end{array}$ & $\begin{array}{l}\text { активність у взаєминах зі студен- } \\
\text { тами; } \\
\text { педагогічне спілкування з досвідче- } \\
\text { ними колегами; } \\
\text { взаємодія з батьками студентів }\end{array}$ \\
\hline Комунікативна & $\begin{array}{l}\text { ерудованість; } \\
\text { витриманість; } \\
\text { риторична культура; } \\
\text { впливовість; } \\
\text { рівень володіння іноземною мовою }\end{array}$ & $\begin{array}{l}\text { тренінги з комунікативної культури } \\
\text { (риторики); } \\
\text { активність у спілкуванні; } \\
\text { курси іноземних мов, } \\
\text { читання спеціальної літератури іно- } \\
\text { земною мовою }\end{array}$ \\
\hline $\begin{array}{l}\text { Інфрормаційно- } \\
\text { технологічна }\end{array}$ & $\begin{array}{l}\text { здатність до використання технічних засобів } \\
\text { навчання (ТЗН), у т. ч. комп'ютерних, на заняттях } \\
\text { різного типу; } \\
\text { здатність знаходити інформацію в різних джере- } \\
\text { лах; } \\
\text { здатність до використання у діяльності Інтернет- } \\
\text { програм }\end{array}$ & $\begin{array}{l}\text { Онлайн-тренінги з підвищення } \\
\text { комп'ютерної грамотності; } \\
\text { активність у інтернет-спілкуванні }\end{array}$ \\
\hline $\begin{array}{l}\text { Управлінсько- } \\
\text { організаційна }\end{array}$ & $\begin{array}{l}\text { здатність передавати свій досвід; } \\
\text { здатність планувати навчально-виховний процес } \\
\text { загалом (тематично, календарно); } \\
\text { здатність до планування й реалізації програми } \\
\text { власного професійного розвитку; } \\
\text { здатність до організації контролю навчальних } \\
\text { досягнень студентів; } \\
\text { здатність передбачати наслідки професійної } \\
\text { діяльності, обирати найбільш ефективні способи } \\
\text { їі реалізації (рефрлексія) }\end{array}$ & $\begin{array}{l}\text { робота у методичних комісіях; } \\
\text { виступи на педагогічних радах, } \\
\text { семінарах, конфреренціях; } \\
\text { самонавчання та самовдоскона- } \\
\text { лення }\end{array}$ \\
\hline Наукова & $\begin{array}{l}\text { Публікаційна активність, участь у наукових захо- } \\
\text { дах, популяризація власних наукових доробок, } \\
\text { залучення до наукової співпраці студентів, участь } \\
\text { у наукових конкурсах, Грантах, госпдоговірних } \\
\text { наукових темах, членство у Радах із підготовки } \\
\text { кадрів вищої кваліфікації, у редколегіях наукових } \\
\text { журналів }\end{array}$ & $\begin{array}{l}\text { Участь у конференціях, наукових } \\
\text { семінарах, симпозіумах; } \\
\text { організація наукових заходів для } \\
\text { колег; } \\
\text { підвищення наукової кваліфікації } \\
\text { (аспірантура, докторантура) }\end{array}$ \\
\hline
\end{tabular}

maind-mapping», «Фасилітація як метод активного навчання», «Профресійна риторика: «Особливості роботи з різними аудиторіями слухачів», «Тимбілдинг як інструмент згуртування навчальної групи та педагога» (2019), «Коучингові технології у навчанні», «Технологія скрайбінгу» (2020)) та наукової («Організація публікації у журналах провідних науково-метричних баз» (2020)) компетентності викладача, які дозволяють спрямувати науково-педагогічних працівників вищої школи на застосування сучасних методів і технологій у взаємодії зі студентами. 
У межах роботи представленої науково-практичної школи-семінару упродовж двох років взяли участь більше 400 викладачів закладів вищої освіти із різних регіонів України. У 2019 р. авторські програми були представлені у вигляді тренінгів, учасникам було надано методичні розробки (у т. ч. презентації, відеофайли) для реалізації кожної з обраних програм у власній діяльності. Відгуки, отримані від учасників заходу, свідчили про його високу цінність і затребуваність. Однак було зазначено, що певні програми бажано було б деталізувати у більш широкому форматі. Організатори заходу здійснили ресрлексію діяльності й у 2020 р. представили удосконалені програми підвищення кваліфрікації, розраховані на 8 годин аудиторної та 22 години самостійної роботи кожна. Крім того, в аспекті високого рівня потреб від викладачів гуманітарних дисциплін набуття компетенції, що дозволяла б здійснити публікацію в науковому журналі бази Scopus або Webofsciens, було розроблено авторську програму «Організація публікації у журналах провідних науково-метричних баз». За свідченням учасників програми, набуті компетенції дозволять їм оновити методичний досвід через застосування інноваційних технік і технологій у навчальному процесі. Усвідомлення вимог редколегій провідних наукових журналів і набуття технік роботи 3 науковим текстом зняло напруження учасників щодо страху представлення власних наукових доробок до публікації у цих збірниках.

Слід зазначити, що сучасні виклики, які постали перед освітньою галуззю внаслідок глобальної пандемії, спричинили необхідність знаходження нових форм підвищення кваліфрікації викладачів 3ВО, а отже, перспективним вважаємо розроблення означених курсів у системі MOODLE, що плануємо представити у 2021 p.

Висновки. Аналіз досвіду організації підвищення кваліфікації викладачів ЗВО лонгітюдним способом (щороку по одному кредиту) за накопичувальною системою дозволив зробити висновок про актуалізацію рефрлексії науково-педагогічних працівників щодо власної недосконалості в аспекті сучасних вимог і їхньої активності у виборі форм і способів професійного самовдосконалення. Уважаємо, що саме такий шлях підвищення кваліфікації (а не один на 5 років - за розгорнутою програмою обсягом 180 годин, що представляє одну тему) буде найбільш ефективним для якісного оновлення викладачів вищої школи.

Отже, можна стверджувати, що свідоме поступове накопичення актуального і сучасного педагогічного досвіду викладача університету свідчить про ссрормованість його самоосвітньої компетентності.

\section{БІБЛІОГРАФІЧНИЙ СПИСОК:}

1. Вовк Б. Мотиваційна складова самоосвіти майбутніх викладачів практичного навчання. Наукові записки. Серія: Педагогічні науки. Вип. 147, C. 184-188. URL: file:///C:/Users/3671 1/AppData/ Local/Temp/Nz_p_2016_147_49.pdf.

2. Кайдалова Л.Г. Самоосвіта і самовдосконалення викладача вищого навчального закладу. Проблеми трудової та професійної підготовки. Серія 134 «Основні компоненти інновацій у профеесійній підготовці майбутніх вчителів». 2011. Вип. 17. С. 40-48. URL: http://dspace.nuph.edu.ua/ handle/123456789/296.

3. Перкатий Р. Сутність, зміст та структура самоосвітньої компетентності майбутніх осріцерів національної поліції. Збірник наукових праць Національної академії Державної прикордонної служби України. Серія: Педагогічні науки. 2016. № 4. С. 183-193. URL: http://nbuv.gov.ua/UJRN/znpnadpcpn_2016_4_19.

4. Постанова Кабінету Міністрів України від 21 серпня 2019 р. № 800 Про порядок підвищення кваліфікації педагогічних і науково-педагогічних працівників. URL: https://zakon.rada.gov.ua/laws/ show/800-2019-\%D0\%BF\#Text.

5. Самарук Н. Структура та педагогічні умови формуванян самоосвітньої компетентності майбутніх фахівців. Молодь і ринок. № 9 (176). 2019. C. 75-81. URL: file:///C:/Users/3671 1/AppData/Local/ Temp/Mir_2019_9_16.pdf. 